\title{
Re-envisioning the School Day: \\ Integrating Mathematics, Science, and Reading through Students' Engagement with Practices
}

Temple A. Walkowiak, James Minogue, Ann D. Harrington, Cynthia P. Edgington

\begin{abstract}
In this article, we propose an alternative to traditional content integration that has resulted in our preservice elementary teacher candidates designing lessons centered on developing focused practices throughout a re-envisioned school day. We first present connections among the practices outlined in mathematics, science, and reading standards; the complementary nature of the practices creates a conceptual thread that weaves through and helps unite content across disciplines. Then, we outline the project that our teacher candidates complete, with descriptions of resulting examples of their work. We conclude by presenting suggestions for educators and other leaders who are interested in utilizing this lesson planning approach in their own settings.
\end{abstract}

Keywords: standards-based practices, elementary school, lesson planning, mathematics, science, reading

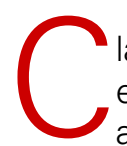

lassroom teachers are often encouraged to integrate content across disciplines (Fogarty \& Pete, 2009), particularly at the elementary level. Curriculum integration can be a challenge, due, in part, to the demands of teaching in this era of high-stakes testing and accountability (Brand \& Triplett, 2012). We propose an alternative to traditional content integration that has resulted in our teacher candidates designing lessons centered on developing focused practices (e.g., argumentation, asking questions, and using models) across the school day. In most recent standards documents such as the Common Core State Standards (CCSS; NGA \& CCSSO, 2010) and the Next Generation Science Standards (NGSS; Lead States, 2013), practices are emphasized with the expectation that students are engaging with high-level practices as they learn content.

We are teacher educators at the same university working collaboratively to prepare our candidates to become elementary-school teachers, but we each focus on different disciplines (mathematics, science, and reading education). Our teacher candidates take discipline-specific methods courses focused on the upper elementary grades (3-5) in the same semester. The ideas presented in this article result from the implementation of a crosscourse, lesson-planning project. This article has three aims:

1) to describe the project and its goals;

2) to provide resulting examples; and

3) to present suggestions for educators and other leaders who would like to implement this approach to lesson planning.

While our work is situated in the elementary grades, we believe the approach presented herein can translate to middle and high school contexts with some modifications, as detailed in the article's conclusion.

\section{THE PROJECT}

The purpose of the multi-course project is twofold. First, it is designed to help teacher candidates think more deeply about new ways to organize a full day of instruction around common practices found in national standards. Second, an important byproduct of this project is that the students in the classrooms of our teacher candidates develop an appreciation for how the curricula of various subjects connect to and build on each other. The type of curricular integration we are describing moves beyond a 
thematic unit focused on a single topic. For example, a unit on "bears" may include students researching facts about bears in science, solving story problems about bears in math, and reading a book about bears. These tasks may lead to students making only superficial content connections and learning surface-level content.

Our integration model is not driven by content demands, but is instead driven by the development of standards-based practices (NGA \& CCSSO, 2010: Lead States, 2013). The complementary practices become the conceptual thread that weaves through and helps unite the content. If selected and leveraged thoughtfully, the targeted set of related practices lend much-needed coherence to the work that students do in a given school day.

When one examines the individual sets of practice standards for mathematics, science, and reading, the connections become apparent, and the common educational aim of preparing citizens for critical thinking, problem solving, and communication skills required for careers becomes self-evident (Stage, Asturias, Cheuk, Daro, \& Hampton, 2013). The Standards for Mathematical Practice (SMPs) in the CCSS for Mathematics (CCSS-M) (URL:

http://www.corestandards.org/Math/Practice/) build on previous standards (NCTM, 2000) and years of research about the ways children learn mathematics. For example, we know the ability to "construct viable arguments" is important to make sense of mathematical concepts and deepen understanding and, in fact, is a practice in which mathematicians engage. Similarly, scientists "engage in arguments with evidence" when they share findings and claims from investigations, hence the reason the Scientific and Engineering Practices in the NGSS (URL: http://www.nap.edu/read/13165/chapter/7) outline that K-12 students should engage in this practice while learning science content. NGSS portrays a vision of "three-dimensional learning" to include content knowledge, crosscutting concepts, and science and engineering practices. 3-D learning engages students with the practices in the context of a core idea and crosscutting concepts (e.g., patterns, cause and effect). Like the CCSS-M and the NGSS, the Reading Anchor Standards of the CCSS for English Language Arts (URL:

http://www.corestandards.org/ELALiteracy/CCRA/R/) suggest practices in the form of general expectations for what students should be able to do as readers across grade levels. The anchor standards "define general, cross-disciplinary expectations for College and Career Readiness" (Cunningham \& Cunningham, 2015, p. 2). The types of learning experiences advocated by each set of standards are exciting, but to become a reality for students, lesson planning needs to be fueled by both the content and practices.

For the assigned project, teacher candidates chose one practice from each set of standards to develop throughout a school day. Chosen practices had to be complementary or synergistic; in other words, there had to be an overarching thread that tied the practices together. Table 1 displays three examples of practice connections that our teacher candidates used. Candidates developed lessons for mathematics, science, and reading to meet focal content standards, based on the pacing guides provided by the school system in which our candidates are teaching. The candidates' lesson plans had to address how the selected tasks promoted their elementary students' use of the chosen practices. Furthermore, candidates were required to make the goal of developing the practices explicit to their students throughout the school day. 
Table 1

Example Connections ${ }^{1}$ among Practices in National Standards

\begin{tabular}{|c|c|c|c|}
\hline $\begin{array}{l}\text { Standards for } \\
\text { Mathematical } \\
\text { Practice } \\
\text { (CCSS-M) }\end{array}$ & $\begin{array}{l}\text { Practices in the } \\
\text { Next Generation } \\
\text { Science Standards } \\
\text { (NGSS) }\end{array}$ & $\begin{array}{l}\text { Reading and Language } \\
\text { Arts (CCSS-ELA) }\end{array}$ & $\begin{array}{l}\text { Connecting } \\
\text { Thread }\end{array}$ \\
\hline $\begin{array}{l}\text { Make sense of } \\
\text { problems and } \\
\text { persevere in } \\
\text { solving them }\end{array}$ & $\begin{array}{l}\text { Asking questions } \\
\text { (for science) and } \\
\text { defining problems } \\
\text { (for engineering) }\end{array}$ & $\begin{array}{l}\text { Analyze how and why } \\
\text { individuals, events, or } \\
\text { ideas develop and } \\
\text { interact over the course } \\
\text { of a text }\end{array}$ & $\begin{array}{l}\text { Problem } \\
\text { Solving }\end{array}$ \\
\hline $\begin{array}{l}\text { Model with } \\
\text { mathematics }\end{array}$ & $\begin{array}{l}\text { Developing and } \\
\text { using models }\end{array}$ & $\begin{array}{l}\text { Analyze the structure of } \\
\text { texts, including how } \\
\text { specific sentences, } \\
\text { paragraphs, and larger } \\
\text { portions of the text (e.g., } \\
\text { a section, chapter, } \\
\text { scene, or stanza) relate } \\
\text { to each other and the } \\
\text { whole }\end{array}$ & Modeling \\
\hline $\begin{array}{l}\text { Construct viable } \\
\text { arguments and } \\
\text { critique the } \\
\text { reasoning of } \\
\text { others }\end{array}$ & $\begin{array}{l}\text { Engaging in } \\
\text { argument from } \\
\text { evidence }\end{array}$ & $\begin{array}{l}\text { Delineate and evaluate } \\
\text { the argument and } \\
\text { specific claims in a text, } \\
\text { including the validity of } \\
\text { the reasoning as well as } \\
\text { the relevance and } \\
\text { sufficiency of evidence }\end{array}$ & Argumentation \\
\hline
\end{tabular}

${ }^{1}$ This table is not exhaustive in terms of connections among practices. 


\section{EXAMPLES}

We now turn our attention to two of our teacher candidates by describing their lessons and how they integrated their instruction through practices, rather than content.

Ms. Hamilton. Ms. Hamilton (pseudonym) re-envisioned the school day by anchoring her fifth-grade lessons around the practice of "modeling." As Ms. Hamilton said, "people use modeling every day to help them visualize or consolidate information." Ms. Hamilton began her school day with a reading lesson focused on analyzing the structure of text (e.g., the author's use of headings, subheadings, and paragraph structure) and using models for comprehension. Students read an article about the "Great Pacific Garbage Patch (GPGP)," a vortex in the northern part of the Pacific Ocean with high concentrations of chemical sludge and other debris. Ms. Hamilton's students used the structure of the text to create their own graphic organizer that became a model to show the relationships among humans, the GPGP, and sea organisms.

After the reading lesson, Ms. Hamilton taught her science lesson, where she also utilized the use of models. Her students sorted pictures of sea organisms into three categories: producers, consumers, or decomposers. Then, they completed the same sorting activity, but the pictures included descriptions and names for each organism. The additional information allowed students to correct their misconceptions. Ms. Hamilton and her class then discussed if the current models (from sorting) showed the relationships between and among the organisms. When they agreed that no relationships were shown, students created food chains and subsequently engaged in a discussion about how their new models helped them understand relationships and deepen their knowledge of sea organisms.

Later in the school day, Ms. Hamilton's mathematics lesson involved students modeling a real-world mathematical situation. A packaging company needs to make a box (rectangular prism) with a volume of 24 cubic inches for holding a serving of popcorn. The students built the various box options using multi-link cubes and documented each box's dimensions. Then, they recommended and justified a popcorn box option to the packaging company. Students utilized modeling while building their conceptual understanding of volume.

Ms. Norton. Ms. Norton (pseudonym) focused her re-envisioned school day in fourth grade on argumentation; in her words, the focus "allowed the students to develop an in-depth understanding of the topics at hand." Her day began with a mathematics lesson focused on decimals and place value. Before any formal instruction, students worked in pairs to respond to a mathematical statement (e.g., 0.1 is equal to $1 / 100)$. They wrote arguments as to whether the statement was true or false and provided supporting evidence, and then exchanged papers with another pair to provide critique of each other's argument. After a lesson on decimals and place value, the students examined their original arguments and peers' critique, and revised as necessary.

In reading, students worked in trios to develop an argument about the pros and cons of recycling after reading an article on the topic. They used evidence from the text to support their arguments and engaged in a whole-class debate. After the debate, students worked individually to write an argument with supporting details either in support or against recycling.

In science, Ms. Norton taught a lesson on the basic differences among sedimentary, igneous, and metamorphic rocks. Then, working in small groups, students examined a rock provided by Ms. Norton. They developed an argument for how they classified the rocks by citing specific evidence, and then created a short video of their arguments. Students 
watched each other's videos and critiqued the arguments.

\section{OUTCOMES}

Ms. Hamilton, Ms. Norton, and most of our other teacher candidates reported on the power of integrating through practices across the typically separate disciplines, both in their students' experiences and in their own pedagogy. One teacher candidate commented that her re-envisioned day gave students new "insight on strategies they can use to learn across multiple content areas, as opposed to viewing learning as having different approaches to each new concept." Ms. Hamilton commented on her own instructional practice, stating she found herself paying "more attention to observing students' progress to check that they were developing the practices."

\section{SUGGESTIONS}

The outcomes of our teacher candidates' projects indicate this approach to lesson planning has the potential to heighten students' and teachers' appreciation for the many ways the various "subjects" connect to and complement each other. After implementing this project with two cohorts of teacher candidates, we offer three suggestions for other educators interested in using this lesson planning approach.

Ensure a clear thread exists to tie the practices across the disciplines together. There are numerous connections across the practices in the national standards that can be made. However, the key is to ensure the thread or glue that connects practices from different disciplines together is apparent. In the case of our teacher candidates, we had a few candidates whose targeted practices were only superficially related. The stronger units of instruction synthesized the full text descriptions of the targeted standards before building a day of instruction focused on the development of practices within and across disciplines.
Keep the content objective central to the lesson, making sure it does not get lost. While it is exciting to get students engaged in targeted practices, it is important that the content to be developed does not get lost. This loss of content happened for some of our teacher candidates in that the lessons they planned emphasized students' development of the selected practices at the expense of the content learning objectives. As teachers identify both practices and content objectives during planning, teachers need to verify that the practice is developed through the content. The learning objectives should remain the driving force behind the features of any activity, while the practice becomes explicit in the ways that students engage with the content. Simply put, it is important to ensure that the content covered will allow you to "feed" the development of the chosen practice.

Be explicit with students about the practice(s) they are developing. We alluded to this point earlier, but we want to emphasize its importance. It is essential to make the connections explicit to the students throughout their work by using sentence frames such as the following: "Remember when you were using evidence in your arguments about in science. We can make similar evidence-based arguments in math/reading when we ___, or "Just as we used a model of to represent in science, we can use models in math to reason about

\section{CONCLUSION}

Although our teacher candidates work in elementary settings where teachers typically teach multiple subjects, we argue this approach to lesson planning could also be implemented in middle or high schools. In middle schools that utilize teaming, common practices can become part of planning discussions, and teams could focus on common practices as students move among classrooms throughout the day. In cases where there are not teams, as is true in 
many high schools, a solution may be that multiple departments focus on the development of a common practice for a unit of instruction.

For example, the mathematics and science departments could choose to focus on argumentation for a duration of time in all of the courses they teach. In so doing, students would experience practice-based connections across the disciplines. Another approach could be a school-wide focus on common practice(s) for an extended period of time (e.g., an academic quarter). This approach could be beneficial for schools who utilize semester-long courses where students do not necessarily enroll in both a mathematics and science course, for example, in the same semester.

With the clear attention to developing practices found in the standards, this powerful approach to lesson planning is a natural and appropriate way to integrate instruction. This form of planning has the potential to unveil for students how their work as mathematicians, scientists, and readers are actually quite similar. One of our teacher candidates captured the power of this lesson planning approach well when she said:

Highlighting a common practice across multiple content areas unifies instruction and enables students to better transfer their knowledge. It shows students that education is not compartmentalized; that is, the methods of thinking that they learn in one subject can and should be used in other disciplines, both in and out of the classroom.

We believe this unification of instruction can bring coherence to the work of teachers' daily planning and can in turn create new feelings of excitement and efficiency.

\section{REFERENCES}

Brand, B. R., \& Triplett, C. F. (2012). Interdisciplinary curriculum: an abandoned concept? Teachers and Teaching: Theory and Practice, 18(3),
381-393.

http://dx.doi.org/10.1080/13540602.201 2.629847

Cunningham, P.M. \& Cunningham, J.W. (2015). Teaching Common Core English Language Arts Standards: 20 Lesson Frameworks for Elementary Grades. Bloomington, IN: Solution Tree.

Fogarty, R. J., \& Pete, B. M. (2009). How to Integrate the Curricula. Thousand Oaks, CA: Corwin Press.

Lead States. (2013). Next Generation Science Standards: For States, By States. Washington, DC: The National Academies Press. https://www.nap.edu/catalog/18290/nex t-generation-science-standards-forstates-by-states

National Council of Teachers of Mathematics (2000). Principles and Standards for School Mathematics. Reston, VA: Author.

National Governors Association Center for Best Practices \& Council of Chief State School Officers (2010). Common Core State Standards. Washington, DC: Author. http://www.corestandards.org/

Stage, E. K., Asturias, H., Cheuk, T., Daro, P. A., \& Hampton, S. B. (2013). Opportunities and challenges in next generation standards. Science, 340(6130), 276-277. DOI:10.1126/science.1234011

\section{ABOUT THE AUTHORS}

Temple A. Walkowiak is an assistant professor of mathematics education in the Department of Teacher Education \& Learning Sciences at North Carolina State University. James Minogue is an associate professor science education in the Department of Teacher Education \& Learning Sciences at North Carolina State University. Ann Duffy Harrington, and Cynthia P. Edgington are assistant professors in the College of Education at North Carolina State University in Raleigh, North Carolina. 